\title{
Monetary Sanctions and Housing Instability
}

\author{
MARY PATTILLO॰, ERICA BANKS, BRIAN SARGENT, AND \\ DANIEL J. BOCHES
}

The relationship between criminal legal involvement and housing is complex because the causal arrow goes both ways. Research documents a homelessness-incarceration nexus whereby homelessness is criminalized, and incarceration leads to homelessness. In this article, we broaden the scope of housing outcomes by considering housing instability more generally and we shift the focus to legal financial obligations (LFOs) as a specific kind of criminal legal sanction, apart from incarceration or the effects of a record. Our data consist of surveys and qualitative interviews with people paying LFOs $(N=519)$, interviews with court actors $(N=443)$, and more than 1,900 hours of courtroom ethnography in eight states, plus nationally representative survey data. We find substantial evidence of a housing instability-LFO nexus, a caustic churn whereby a population with identifiable housing hardships is saddled with a punishment that deepens financial strain and thus weakens housing stability.

Keywords: housing instability, homelessness, legal financial obligations, monetary sanctions

The double punch of too little affordable housing and a scarcity of living-wage jobs puts millions of people in situations of overcrowding, poor housing quality, housing cost burden, evictions, transience, and homelessness (Cox et al. 2019; Pattillo 2013). Housing is ostensibly a civil issue, not a criminal one. Code violations, formal evictions, and lease disputes are adjudicated in civil courts. However, many laws that govern the use of public space "expand the number of behaviors subject to investigation, arrest, and incarceration" on the criminal side

Mary Pattillo is the Harold Washington Professor of Sociology and African American Studies at Northwestern University, United States. Erica Banks is a doctoral candidate in the Department of Sociology at Northwestern University, United States. Brian Sargent is assistant professor of public policy and sociology at the University of Massachusetts Amherst, United States. Daniel J. Boches is a doctoral candidate in the Department of Sociology at the University of Georgia, United States.

(C) 2022 Russell Sage Foundation. Pattillo, Mary, Erica Banks, Brian Sargent, and Daniel J. Boches. 2022. “Monetary Sanctions and Housing Instability." RSF: The Russell Sage Foundation Journal of the Social Sciences 8(2): 57-75. DOI: 10.7758/RSF.2022.8.2.03. This research was funded by a grant to the University of Washington from Arnold Ventures (Alexes Harris, PI). We thank the faculty and graduate student collaborators of the Multi-State Study of Monetary Sanctions for their intellectual contributions to the project. Partial support for this research came from a Eunice Kennedy Shriver National Institute of Child Health and Human Development research infrastructure grant, P2C HD042828, to the Center for Studies in Demography and Ecology at the University of Washington. Direct correspondence to: Mary Pattillo, at m-pattillo@northwestern.edu, Department of Sociology, Northwestern University, 1810 Chicago Avenue, Evanston, IL 60208, United States.

Open Access Policy: RSF: The Russell Sage Foundation Journal of the Social Sciences is an open access journal. This article is published under a Creative Commons Attribution-NonCommercial-NoDerivs 3.0 Unported License. 
(Beckett and Herbert 2008, 6). ${ }^{1}$ In this article, we identify a number of housing-related issues that land people in criminal courts and result in legal financial obligations (LFOs). LFOs are fines, fees, costs, and other monetary sanctions that are sentenced in traffic and criminal courts. We then illustrate how monetary sanctions, in turn, limit and worsen housing options.

Research documents how homelessness is criminalized through bans on panhandling, loitering, squatting, and sleeping on the public way. These laws sweep many unhoused people into jails. At the same time, short jail stays and longer incarceration disrupt earnings and public benefits, which can spiral defendants into homelessness. In this article, we broaden the scope of the effects of criminal legal contact by considering housing instability more generally-from living with extended family, to frequent moves, to inability to pay rent, to homelessness-and shift the focus to look at financial penalties as a specific kind of criminal legal sanction apart from incarceration or the effects of a criminal record. We use multiple data sources and methods: qualitative interviews with court actors, interviews and surveys with people paying criminal legal debt, and courtroom observations, all from the MultiState Study of Monetary Sanctions (Harris, Pattillo, and Sykes 2022, this volume). We also present data from the first national-level survey that includes a question on criminal legal debt from the Federal Reserve (2020b). Across these sources, we find robust evidence of a housing instability-LFO nexus, a caustic churn whereby a population with identifiable housing hardships is saddled with a punishment that deepens financial strain and thus weakens housing stability.

\section{BROADENING FROM HOMELESSNESS} TO HOUSING INSTABILITY

The homelessness-incarceration nexus refers to the cyclical relationship between the criminalization of homelessness and the housing destabilizing effects of incarceration (Metraux, Roman, and Cho 2007). Although homelessness is by no means the primary route into incarceration and incarceration is not the primary driver of homelessness (Shinn and Khadduri 2020), each clearly increases the risk of the other. "Crimes of desperation" (Gowan 2002) alongside public "order" and "civility" laws against panhandling, public drinking, trespassing, camping, loitering, and other behaviors help explain how people experiencing homelessness end up in jails and prisons. Once released, former detainees face myriad barriers to stable housing, including outright prohibitions of people with a criminal record in public and subsidized housing, the stigma of a criminal record in the unsubsidized sector, inability to pay rent because of unemployment, and frayed ties with family members, which added together can land people on the street (Cox et al. 2021; Geller and Curtis 2011; Herbert, Morenoff, and Harding 2015; Petersilia 2003; Western 2018).

Between 10 to 15 percent of people incarcerated in jails and prisons experienced homelessness in the year prior to incarceration (Greenberg and Rosenheck 2008; Harlow 2003; James 2004). Conversely, people who have experienced incarceration are four (Geller and Curtis 2011) to ten (Couloute 2018) times as likely to be homeless as the general population. Further, the impacts of incarceration and homelessness seem to be intergenerational: the incarceration of Black fathers increases the likelihood of homelessness among their children (Wildeman 2014), and childhood homelessness is positively correlated with adult incarceration (Cobb-Clark and Zhu 2017). The homelessness-incarceration nexus illustrates the multiple domains of exclusion experienced by vulnerable populations, locked out of housing, locked up in jails and prisons, and locked into a cycle that repeatedly connects the two (Evans 2007).

The collateral housing consequences of incarceration go beyond homelessness to include housing instability and insecurity, defined as

1. The 2019 Supreme Court decision in Martin v. City of Boise (902 F. 3d 1031, 1048 [9th Cir. 2018]) has called into question the ability to criminalize sleeping in public if no shelter beds are available, but it remains to be seen how municipalities respond to this ruling. Also, criminal law aimed at people without housing goes beyond antisleeping ordinances. 
the "inability to acquire stable, safe, adequate, and affordable housing and neighborhoods in socially acceptable ways" (Cox et al. 2019, 99). For example, incarceration leads to a lower probability of homeownership and negatively affects transitions into and duration of homeownership (Bryan 2020); it also increases the likelihood of skipping a mortgage payment (Geller and Curtis 2011). On residential mobility, David Harding, Jeffrey Morenoff, and Claire Herbert find that parolees in Michigan averaged 2.6 moves per year, which they characterize as "a very high level of residential mobility, a level not seen in most other populations" $(2013,226)$. The positive relationship between incarceration and housing instability (beyond homelessness) is replicated in several other studies (Evans and Porter 2015; Geller and Franklin 2014; Herbert, Morenoff, and Harding 2015; Halushka 2020; Keene, Smoyer, and Blankenship 2018; Richie 2001; Warner 2015).

Research is sorely lacking on how housing instability beyond homelessness can lead to incarceration. One retrospective study found that incarcerated populations experienced significant residential instability prior to detention, which illustrates the pathway from housing instability into first incarceration (Muentner et al. 2019). Yet the strongest evidence comes from studies of recidivism showing that unstable housing after incarceration increases the likelihood of reoffending and thus reincarceration (Clark 2016; Jacobs and Gottlieb 2020; Steiner, Makarios, and Travis 2015). The reverse is also true: programs that provide stable housing for formerly incarcerated people facilitate reintegration and reduce recidivism (Cobbina 2010; Kirk et al. 2018). Studying the criminalization of housing instability-beyond homelessness and outside of the context of reentry-is an original contribution of this article.

\section{SHIFTING FROM INCARCERATION TO LEGAL FINANCIAL OBLIGATIONS}

Much of the research on criminal sanctions focuses on incarceration. Fines and fees, however, are a ubiquitous part of criminal punishment and deeply encumber people's social, civil, and working lives (Harris 2016; Martin et al. 2018). Financial penalties are a criminal legal sanction that directly affect the ability to afford the necessities of daily life. Monies used to pay LFOs are unavailable to pay for food, transportation, health care, and housing.

Studies in the growing field of monetary sanctions mention housing instability as a sequela of being sentenced to pay fines and fees, but often place housing alongside other hardships that result from LFOs (Bannon, Nagrecha, and Diller 2010; Harris 2016; Harris, Evans, and Beckett 2010). Only Jessica Mogk and her colleagues (2020) make the relationship between LFOs and housing outcomes-specifically homelessness - the primary topic of study. In their survey of 101 people experiencing homelessness in Seattle, they found that having criminal legal debt was correlated with longer periods of homelessness. Expanding on that work, we explore how LFOs produce many forms of housing insecurity.

How housing instability leads to LFOs is a more difficult process to document, but we exploit our wealth of data to forge new hypotheses for this pathway. Again, the role of homelessness is much better understood. Being homeless leads directly to financial penalties in jurisdictions where public order infractions receive fine-only citations. The homeless men in Forrest Stuart's ethnographic study in Los Angeles, for example, received criminal fines for jaywalking, begging, obstructing the sidewalk, littering, and "flicking ... cigarette ash into the breeze" (2016, 5; also see Herring, Yarbrough, and Alatorre 2020). Beyond homelessness, we show how other forms of housing insecurity-such as living in crowded housing situations with few resources-can also lead to entanglements with the law and result in fines and fees.

Building on the housing and criminal legal literatures, the model in figure 1 captures the recursive relationship between housing insecurity broadly and LFOs in particular. Driving the model are the individual and structural factors of widespread vulnerability among both people who experience housing problems and people involved in the criminal legal system. At the individual level, both populations have low incomes, and some face personal drug and mental health challenges. At the structural level, the misalignment of the housing and labor markets creates housing insecurity, and the stigma of having a criminal background makes it 
Figure 1. Model of Housing Instability-LFO Nexus

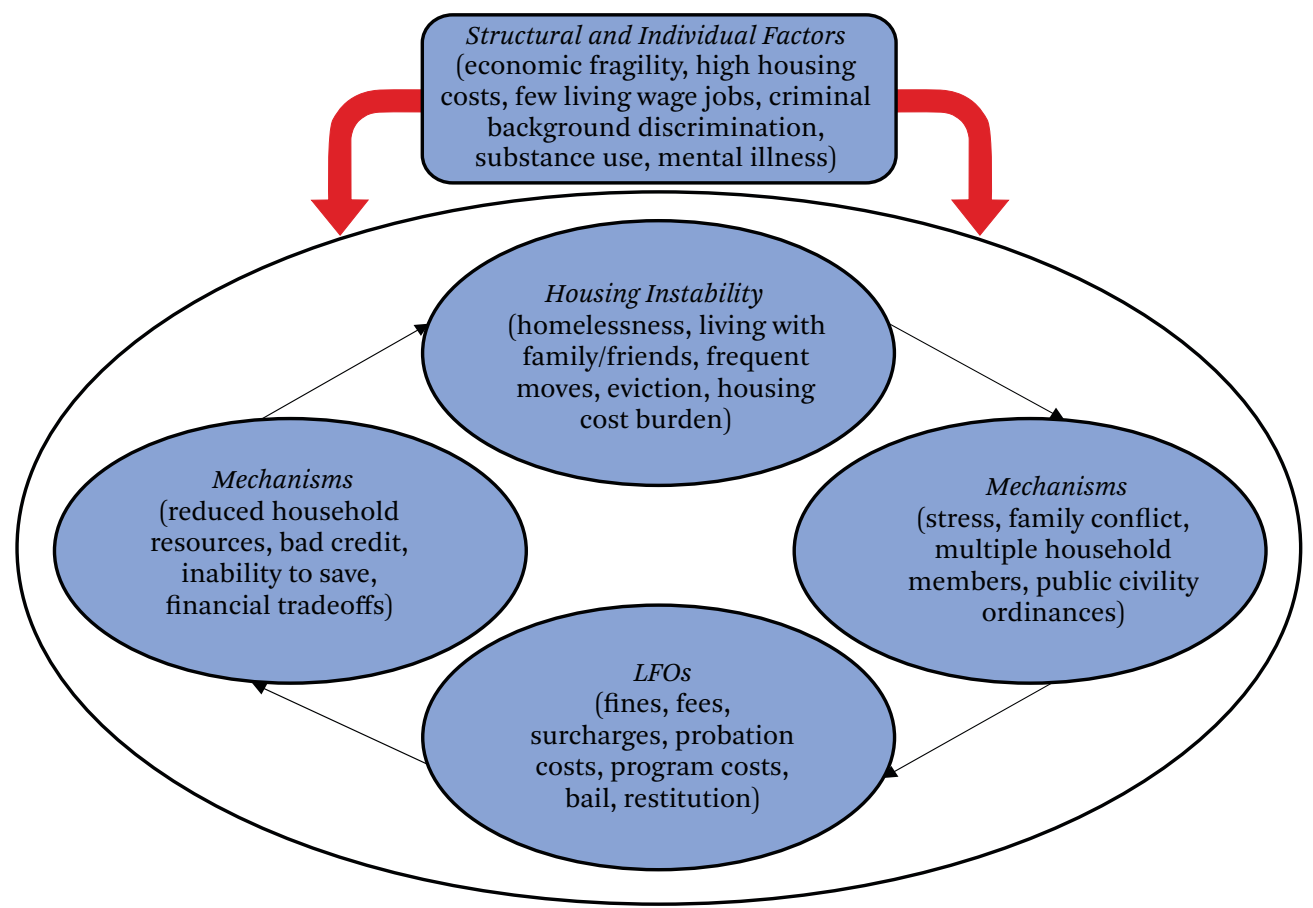

Source: Authors' illustration.

harder to secure housing. ${ }^{2}$ We do not prescribe where the inner circle depicted in figure 1 begins-with housing problems or criminal legal debt. Even though housing issues likely precede criminal legal involvement over the life course, someone in stable housing could be sentenced to pay LFOs for reasons completely unrelated to housing, and that new financial obligation might throw them into housing instability. Hence we emphasize the loop between the two. Using the data described in the next section, we elucidate the stress, household conflict, and legal mechanisms that lead from housing instability to LFOs, and the resource and credit issues that lead from LFOs to housing instability.

\section{DATA AND METHODS}

We use data from eight states included in the Multi-State Study of Monetary Sanctions: Cali- fornia, Georgia, Illinois, Minnesota, Missouri, New York, Texas, and Washington (for a full discussion of the data and methods of this study, see Harris, Pattillo, and Sykes 2022, this volume). The data consist of surveys and qualitative interviews with 519 people with LFO sentences about their interactions with the courts and how monetary sanctions affected their lives; qualitative interviews with 443 court actors-judges, prosecutors, defense attorneys, probation officers, and court clerks - which add an important balance to the perspective of defendants, and which are unique to our study; and more than 1,900 hours of courtroom observations across the eight states. Data were collected between 2016 and 2018. We inquired directly about housing only in the interviews and surveys with people sentenced to LFOs. Nonetheless, court actors offered unprompted information about housing, and housing matters

2. Beyond the general negative impact of having a criminal background on housing outcomes (Thacher 2008), people convicted of sex crimes and domestic violence are particularly constrained in their housing options because of both the greater stigma (Evans and Porter 2015) and locational restrictions (Zgoba, Levenson, and McKee 2009). 
Table 1. Housing Characteristics of People with LFOs ( $\mathrm{N}=519)$

\begin{tabular}{lr}
\hline Housing characteristics & \\
\hline Ever experienced homelessness & $50 \%$ \\
Housing type & \\
Homeless & $5 \%$ \\
Shelter or transitional housing & $11 \%$ \\
Residence of friends or family & $31 \%$ \\
Own home or apartment & $54 \%$ \\
Housing tenure & \\
Renter & $66 \%$ \\
Owner with mortgage & $13 \%$ \\
Other pay situation & $7 \%$ \\
Rent free & $14 \%$ \\
Receiving housing assistance & $18 \%$ \\
Mean monthly housing costs & $\$ 660$ \\
\hline
\end{tabular}

Source: Authors' tabulation based on the MultiState Study of Monetary Sanctions, excluding missing data (Harris, Pattillo, and Sykes 2022).

also came up during court proceedings. References to housing totaled 742 pages of data across the eight states for those paying court debt, 749 pages of data among court actors, and 47 pages of ethnographic data.

Table 1 presents information from the surveys with people paying court debt. The sample is racially diverse, two-thirds male, predominately low-income, and with high rates of unemployment.

Table 1 shows that both current and past housing precarity is widespread. Half of the respondents for whom we had data had experienced homelessness in their lives; 11 percent were living in a shelter or other transitional housing at the time of the interview, and 5 percent were living on the street or in their cars. Living with family or friends-31 percent of the sample-is also an important measure of housing insecurity, as we elaborate in the findings. Just over half of the respondents lived in their own home or apartment. Homeowners were a minority of our sample, at 13 percent. Only 18 percent received subsidized housing assistance. Finally, monthly housing costs ranged from $\$ 0$ to $\$ 4,200$, averaging $\$ 660$. Given that the average income of our interviewees was roughly $\$ 1,500$ (data not shown), the average respondent could be classified as housing cost burdened $(\$ 660 / \$ 1,500=0.44)$ because they paid 30 percent or more of their income toward housing (HUD n.d.).

The interview and ethnographic data from all eight states were coded using NVivo qualitative data analysis software. We developed roughly fifty new codes to refine the analysis of the housing-related data (such as overcrowding, frequent moves, housing quality). After coding the ethnographies and two sets of interviews, each coauthor wrote a memo outlining emerging patterns, themes, and findings, which we then discussed in team meetings, which then led to more data analysis. This iterative process forms the basis of our argument about how the housing instability-LFO nexus creates a churn of housing hardship, financial punishment, and weakened housing stability.

We also make use of the first national survey to include a question about court debt. In October 2019, the Federal Reserve Bank fielded the annual Survey of Household Economics and Decisionmaking (SHED) (Federal Reserve $2020 \mathrm{~b}$ ). This is a nationally representative sample of more than twelve thousand respondents covering topics about financial well-being and stress. In 2019, SHED included the question, "Do you or someone in your immediate family currently have any unpaid legal expenses, fines, fees, or court costs?" The question is not ideal because it includes "legal expenses," which could include lawyers' fees, but the other categories in the question align with our inquiry.

\section{HOUSING AND LEGAL FINANCIAL OBLIGATIONS, A NATIONAL PICTURE}

We use the national survey from the Federal Reserve to supplement our analysis of the eight state study data. Do the housing issues we observe qualitatively from a nonrandom sample in eight states appear at the national level? Descriptively, we see broadly similar relationships between having LFOs and various measures of housing insecurity.

Roughly 6 percent of respondents in the Federal Reserve's 2019 SHED panel reported having unpaid legal expenses or court fines and fees. Table 2 compares the housing situation of those with and without LFOs, which is some- 
Table 2. Proportions Experiencing Select Housing Conditions by Court Debt

\begin{tabular}{lcc}
\hline & $\begin{array}{c}\text { Without CJ Debt } \\
(\mathrm{N}=11,444)\end{array}$ & $\begin{array}{c}\text { With CJ Debt* } \\
(\mathrm{N}=691)\end{array}$ \\
\hline Homeowner & 0.68 & 0.46 \\
Average household size & 2.47 & 2.76 \\
Adult child in household & 0.15 & 0.18 \\
Lives with parent & 0.09 & 0.12 \\
Lives with siblings, relatives, or unrelated people & 0.11 & 0.19 \\
Moved within last two years & 0.19 & 0.32 \\
Reasons for moving among renters & & \\
Evicted & 0.03 & 0.14 \\
Landlord told respondent to leave & 0.05 & 0.17 \\
Missed rent and thought would be evicted & 0.02 & 0.11 \\
Reasons for renting among renters & & \\
Cannot qualify for mortgage & 0.38 & 0.64 \\
Cannot afford down payment & 0.61 & 0.82 \\
Housing cost burden & & 0.50 \\
Renters & & 0.20 \\
Owners & 0.45 & \\
\hline
\end{tabular}

Source: Authors' tabulation of data from 2019 SHED (Federal Reserve 2020b).

*All differences except for the estimation of Housing Cost Burden are significant at the $p<.01$ level based on Chi-squared test (t-test for Average household size). We thank Tyler Smith for running these analyses.

thing we are not able to do with our qualitative data given that we interviewed and observed only people with court debt. All the differences in table 2-except for housing cost burden, which is an estimate-are significant at the $p<.01$ level.

Table 2 shows that people with LFOs have a higher average household size than those without. Lower proportions of people with court debt are homeowners, and higher proportions have an adult child in the household, live with a parent, or live with other family and nonfamily individuals relative to people without LFOs. Thirty-two percent of those with LFOs moved within the previous two years-a measure of residential mobility-relative to 18 percent of those without. The proportion of renters who reported moving because of eviction, landlord actions, or they had missed a rent payment and assumed they would be evicted was three to five times higher for people with LFOs than for those without. Renters with LFOs stayed renters because they could not save or qualify for mortgages as easily as those without LFOs could. The SHED data allow for only an estimation of housing cost burden-defined as paying 30 percent or more of one's income on mortgage or rent (HUD n.d.) - because both income and housing costs were measured in categories rather than as precise amounts. ${ }^{3}$ Among owners and renters with LFOs, 20 percent and 50 percent, respectively, were housing cost burdened, relative to 13 percent and 45 percent, respectively, of owners and renters without LFOs.

3. We assigned each respondent the midpoint of the range for their reported rent or income. So, someone with rental-mortgage costs from $\$ 1,000$ to $\$ 1,249$ was assigned housing costs of $\$ 1,125$, and someone with a reported income of $\$ 60,000$ to $\$ 74,999$ was assigned an income of $\$ 67,500$, and a monthly income of one-twelfth that amount. This allowed us to compute housing cost burden by dividing the monthly housing cost by the monthly income. We excluded respondents who owned their homes without any mortgage and those who reported neither owning nor renting. 
Taken together, table 2 indicates that people with court debt are more likely to experience housing insecurity that corresponds to the kinds of qualitative experiences we uncover, especially living with family and friends, residential mobility, barriers to homeownership, and struggling to pay for housing (see figure 1).

\section{FROM HOUSING INSTABILITY TO LFOS}

The relationship between housing instability and LFOs is a circular one. We begin our data presentation illustrating the pathway from various kinds of housing instability to the imposition of LFOs under the assumption that it is the most frequent first entry into the recursive relationship illustrated in figure 1.

\section{Homelessness}

A tall White man appeared in a Minnesota courtroom during one of our research teams' observations. He had been in custody for five days and had a public defender who announced that the man was homeless and had several medical issues. The facts of the case as recorded by the fieldworker were as follows: "He got off of a bus and went into the airport to use the bathroom. He then sat down and wouldn't leave immediately when the security asked him to leave." The charge was trespassing and he pled guilty, even though when the judge asked him whether he understood that he was trespassing he answered only, "I guess." The judge imposed a $\$ 50$ fine, but after the defense attorney argued about her client's homelessness, the fine was stayed. This was not a waiver. If the defendant did not comply with the other terms of the sentence, the $\$ 50$ would come due. The judge could not dispense with the \$75 mandatory surcharge, however, and ordered that it be paid over a period of 180 days. ${ }^{4}$ The judge noted that if the defendant did not pay the surcharge at the end of the allotted period, it would be deemed uncollectable. In Minnesota, this meant one of two things: it could be converted into a civil matter and turned over to a collections agency, or it could be written off as a loss by the state agency. ${ }^{5} \mathrm{~A}$ person who used the airport for personal hygiene and refuge owed Minnesota $\$ 75$, and likely $\$ 125$ since the $\$ 50$ would be enforced if the surcharge was not paid.

The literature on the criminalization of homelessness has focused on incarceration. The Minnesota man just discussed indeed spent a few nights in jail awaiting the hearing and sentencing. He was also sentenced to pay LFOs. This scenario was very common in our data, transpiring in every state. Consider the following conversation between sean (all names are pseudonyms), a forty-three-year-old man in Washington State, and the interviewer:

INTERVIEWER: Okay. How much do you worry about your LFOs?

SEAN: I quit worrying about it. I just accepted being homeless.

INTERVIEWER: Yeah?

SEAN: Too poor to make it.

INTERVIEWER: So where do you tend to stay right now?

SEAN: On the street. Like in front of buildings, on the side of buildings. Like I just had court today 'cause I got woken up behind ampm. And so they gave me a trespassing charge for sleeping behind ampm.

INTERVIEWER: Okay. Does that happen more frequently? Or does that happen often, I guess you could say?

SEAN: Yeah, with everyone yeah. It's illegal to be homeless in $[\mathrm{X}]$ county.

INTERVIEWER: It's illegal to be homeless in [X] county?

SEAN: Yeah.

INTERVIEWER: And so you just end up getting all these extra charges on it? Does that add up to more fees and fines and all that?

SEAN: Yeah.

4. See Office of the Revisor of Statutes, "2020 Minnesota Statutes," 357.021 Court Administrator of District Court, Fees; Subd. 6. Surcharges on criminal and traffic offenders, https://www.revisor.mn.gov/statutes /cite/357.021\#stat.357.021.6 (accessed August 12, 2021).

5. See Office of the Revisor of Statutes, "2019 Minnesota Statutes," 16D.04 Collection Activities, https:// www.revisor.mn.gov/statutes/2019/cite/16D.04?keyword_type=exact\&keyword=uncollectible, and 16D.09 Uncollectible Debts, https://www.revisor.mn.gov/statutes/2019/cite/16D.09?keyword_type=exact\&keyword =uncollectible (accessed August 12, 2021). 
INTERVIEWER: So it keeps building?

SEAN: Yeah.

INTERVIEWER: So can you think of ways of getting out [of debt]? Or is it basically like this is just kind of-

SEAN: Get out of $[\mathrm{X}]$ county.

No statute in Washington State or its counties stipulates it is illegal to be homeless. What the law does say, however, is that it is illegal to trespass. Trespassing "upon the premises of another" is what Sean was charged with for sleeping on the property of an ampm convenience store, a simple misdemeanor, punishable by a fine of up to $\$ 1,000$ and a ninety-day jail term. ${ }^{6}$ Sean reported that prior to his arrest, he had received fines and fees of $\$ 1,000$, but that interest for nonpayment had increased them to $\$ 2,500$. Notices about what he owed were sent to his father's house. He was on a payment plan of $\$ 50$ per month. Sometimes his father paid his LFOs and other times he paid them from his monthly disability check, which Sean stated was "supposed to be $\$ 750$. I get $\$ 680$ after child support. And then I have to pay another $\$ 50$ for fines." Sean's LFOs took up 7 percent of his net disability check, which was his only source of income, and was not enough to pay for housing. When asked how the debt affected him, Sean answered directly: "Can't afford to live in the first place, being on disability.... It's affected my ability to pay rent." The circular hardship is obvious. His homelessness gets him fined for trespassing even as his LFOs (and low income) keep him from being housed. ${ }^{7}$

Our study is unique in that we also have the perspective of court actors. A twenty-two-year veteran prosecutor in California described a courtroom episode that deeply affected him. He began by saying, "I will tell you one story that literally brought the courtroom to tears," and then continued with vivid and extensive detail:
[A] young man was ordered to pay restitution for a theft. . . . It was Safeway who was the victim, and it was about $\$ 300$. He was engaged in a shoplifting and had broken a window in attempt to get away. Comes in, the judge says, "Are you prepared to make a payment today? I noticed you haven't made a payment." And he says, "Yes, I have a payment to make." Judge directs him to pay his \$20 to the court officer.

[The judge asks,] "Okay. Um, can you continue to make $\$ 20$ payments?" The defendant said, "I don't know." "Well, why don't you know? Are you employed?" "No, not really." "Where do you live?" ... "I live behind the church." "Okay, so you're saying you're effectively homeless." "Yes." "Where'd you get the \$20 for today?" "I don’t wanna say." "I need you to say. Tell me where you got the \$20." "Well, I did something for it." "What do you mean you did something? Did you steal it?" "No, ma'am. I didn't steal it." "How'd you get it?" "I sold myself."

Judge says, "You sold yourself to someone else to get \$20 to pay restitution?" He said, "Yes." "How'd you get here today?" "I took BART." "Did you pay for BART?" "No, ma'am." "How'd you get here?" "I jumped the turnstile." "So, you sold yourself and you committed an infraction to come here and pay me \$20?" "Yes, ma'am." "And you don't have a place to live tonight?" "No, ma'am." "Give him his money back," the judge told the financial officer. And [the defendant] says, "I don't want it." And [the judge] says, "What do you mean you don't want it? You need the money." And he says, "Your Honor, I don't want it. I don't like what I had to do to get it. I don't want that money."

And the Judge started crying and said, "I'm taking a recess." And nearly brought us all to tears in the room. All of us. And she called us back in her chambers and she said,

6. For criminal trespass in the first degree, see 9A.52.070; for the second degree, see 9A.52.080. On fine amounts, see RCW 9A.20.021.

7. We did not always check court records to verify the LFO amounts that respondents said they owed. Such public records did not exist in many places. Interviewees had no obvious incentive to fabricate their debt or exaggerate their housing precarity. Instead, our sense from doing these interviews was that people were relaying deeply personal experiences. We rely on the sheer volume of corroborating data across the eight states to simply believe their testimonies. 
"What can we do for this young man? What programs does the county have for transitional age youth who need a place to stay? He's not on probation to us for any recent offense, but he owes this debt. Can we do anything?" She called Child Welfare Services, Adult Protective Services, probation. No one could offer a home for this person, and he'd been completely honest and forthright and said this on the record and we were literally at a loss to do anything for this young man, who was maybe eighteen, nineteen.

.... So, I asked the judge to advance the case back on the record, and I said, "Your Honor, would the court consider terminating probation today and we'll prepare paperwork for a 1203.4 petition [to dismiss the case] and get him off of probation and have this expunged from his record?" And the judge said she would. I felt that was the least we could do, as a society. But in the end, when he walked out, I knew [we] hadn't fixed anything for him, really. I hadn't given him a place to stay. I hadn't provided any opportunity, other than to ensure that he didn't have to jump a turnstile or turn any more tricks to come back and pay restitution.

The rapid pace of court processing usually did not allow for the kind of reflection and deliberation that happened in the court that day. Few defendants would be as forthright about their actions, and few judges took the time to inquire. At the case's onset, the defense attorney was primarily concerned with getting his client out of jail. It turned out the defendant was stealing food to feed his younger brother who lived with him on the streets. The financial sentence of restitution (along with likely unmentioned LFOs) surely made it more difficult for this young unhoused person to pay for even temporary shelter. Although the defendant no longer had court debt after the sentence was renegotiated, he still did not have housing. The social service infrastructure was ineffectual, leaving only the punitive arm of the state (for a discussion of the shrinking welfare state and widening criminal legal system, see Fernandes, Friedman, and Kirk 2022; Sykes et al. 2022, this volume).

\section{Living with Family, Frequent Moves, and Household Conflict}

In this section, we broaden the lens to show how housing instability more generally leads to criminal financial sanctions. Although explicit laws on the books criminalize behaviors that unhoused people engage in, and thus strap them with financial penalties, criminal treatment of other forms of housing instability is more indirect. We find that housing instability leads to criminal legal involvement primarily because of family conflict and stress, frequent mobility, and shifting household members, exacerbated by personal factors such as drug use and mental illness. ${ }^{8}$ Living with family or in intergenerational households can be culturally and economically sustaining, but it also presents acute stressors within an overall context of economic fragility. Likewise, residential mobility could in theory improve housing or neighborhood quality, but this was not the predominant experience of the people we interviewed. For example, in Missouri, we observed a court case of a White man in his thirties who was facing a probation revocation. He had been staying with his mother after his conviction, but she threw him out because he wasn't getting along with his stepfather. He did not report to his probation officer that he was no longer living with his mother. This landed him in court on a violation, which opened the door for resentencing, with more LFOs. This story offers a first glimpse of the criminalization of housing instability beyond homelessness, a pathway not previously explored or documented in the literature.

A sizable minority (31 percent) of the people with court debt that we interviewed lived with family members, often for financial reasons (see table 1). "I don't even get ahead before I get knocked back down" is how a twenty-nine-yearold White woman in Missouri described her situation of moving between her grandparents' 
and mother's home. Tensions run high in contexts of frequent moves, little money, and multiple household members. The following story from Delmy-a twenty-five-year-old Black woman in Texas with a monthly income of roughly $\$ 1,600$ but frequent periods of unemployment-chronicles how living with family can lead to criminal legal contact that results in financial penalties. The interviewer asked Delmy how she ended up in the county jail. Delmy answered,

County, I went for several reasons. Okay, I was living with my family member, which is my sister, who called me. . . She was kind of mad that I didn't give her any money. I didn't have any money. Rent, for water, whatever she needed it for. I was just like, I didn't have that. I just started my job. She's just the type, if I make a hundred, she wants eighty. I'm just like, "Okay, what am I going to live on? I can't give you all that I have." She just basically kicked us out. ... Me and my boyfriend at the time. She kicked us out, but she wanted to go out with a fight. She wanted to see this down, like, "I'm going to basically ruin your life." She tried to fight me and I fought back. Then, she made up a whole lie and said that me and my boyfriend jumped her.

Delmy spent a week in jail because of this altercation. This was not her first brush with the law. She had multiple traffic tickets for driving without insurance and an assault charge when she was a juvenile. Delmy's car-related infractions were also housing-related infractions. When the interviewer asked Delmy where she was currently living, she answered, "I just live wherever I may live. Really, in my car. Sometimes we ask people for money to get a hotel or something like that. It's hard. It's been hard." When one's car is one's home, the likelihood of encounters with law enforcement for all manner of daily excursions increases. For Delmy, this resulted in being pulled over for driving while intoxicated. She explained: "[The prosecutor is] trying to tell me the deal's off. I have to pay up all this money, $\$ 800$ and then everything that I owe him far as the fees to get my car out, all based on a DWI [driving while intoxicated conviction] with a cop doing what he did. I'm just like, 'Oh, my God.' Now I'm really setting myself behind, because I was supposed to be in my apartment already. I'm not even stable to even just do anything that normal citizens do, you know?"

The full cycle is apparent in Delmy's recounting. She cannot break free of the churn of unstable housing that leads to court debt that then makes it impossible to stabilize her housing situation. She estimated her monetary sanctions at "I think, over $\$ 5,000$, or $\$ 10,000$. It has to be." Delmy's sister's request for a rent contribution was reasonable, but Delmy had little to give and had a short fuse when her sister asked (on how criminal legal debt affects families, see Boches et al. 2022, this volume). The situation surely also riled Delmy's sister, prompting her to call the police, an escalation that had a price in both Delmy's freedom and her finances. No specific law applied to Delmy's housing situation, but it was the stress of living with her sister that caused the fight that generated criminal legal contact, fines, and fees.

Delmy's husband Lyle (not the boyfriend she was with previously) had a similar story of household conflict that led to his arrest and being sentenced to pay LFOs. "I got a terroristic threat misdemeanor. My biological mom, she's not in her right mind because of substances. But she called [the police], and it was like I went to jail for a terroristic threat. I didn't even get to tell my side of the story. It was like it didn't matter whether I was telling the truth or not ... Misdemeanor Class B."

The volatile situation-which also included the mother's drug-using boyfriend-made it clear that Lyle had to move out of his mother's house, but his mother had already called the police. "I was already gone though, like, already walking down the street with all my stuff," Lyle remembered. Still he was arrested and put in jail. Then the financial penalties accrued. He had to pay for a lawyer. Then he got a toothache while in jail and was charged for medical expenses. "Like, they say when you go to jail your medical is free and all that, but they're really charging you." Once he was sentenced to probation, he had to come up with more money. "Whether you've got to go to weekly check-ins, that cost, or a weekly drug test, that cost." Like Delmy's, Lyle's problematic housing arrange- 
ment led to court involvement and court costs, which in turn contributed to the fact that he and Delmy could not afford regular housing and lived out of their car. Unemployment and substance abuse also clearly played a role, and these are all situations of economic fragility that make it difficult to establish independent residences (see figure 1). The domestic disputes that erupt as a result of the instability of living with family are criminalized, with both legal and financial consequences.

\section{FROM LEGAL FINANCIAL OBLIGATIONS} TO HOUSING INSTABILITY

We now turn to the other half of the pathway; how having LFOs contributes to housing insecurity.

\section{Homeownership}

Only 13 percent of interviewees with court debt were homeowners (see table 1). Studies show that incarceration negatively affects homeownership (Schneider and Turney 2015), but no equivalent research exists on LFOs. Brielle Bryan (2020) finds that conviction alone (without incarceration) is negatively associated with homeownership, a possible indication of the impact of LFOs, but not direct evidence. Whereas incarceration negatively affects employment and reputation and thus income, monetary sanctions damage credit histories and directly encumber financial resources that might otherwise be spent on housing.

Carol, a fifty-one-year-old White woman in New York State, was one of the minority of homeowners we interviewed. She was in court for driving while intoxicated after having been sober for twelve years. "I kinda slipped up," she confessed. She was sentenced to three years of probation and $\$ 995$ in fines and surcharges. Carol had originally set up a \$50 monthly payment plan but returned to court to request a reduction to $\$ 20$ per month because of financial hardship. She had been out of work for more than a year and the previous month she had only seventy-eight cents left in her account after paying her bills and court obligations. She was especially concerned about her home: "I'm not working, and I don't have the money to pay for everything, you know? And I'm afraid that I might have to sell my house ... which is scary, you know? At least I have equity in it because I've been there for so long." Fines and fees are, in part, intended to punish, but to what extent? Carol faced the possibility of losing her house because of the financial costs associated with a DWI, which would represent both losing shelter and housing equity wealth.

Few of our interviewees were homeowners, but many aspired to be. Credit was among the top five most prevalent codes in the analysis of the data from people with LFOs, indicating the barrier that credit problems presented for both renting and buying a home. Prentice, a fortyone-year-old Black man also in New York, said, "I can't even buy a house or own a house in [X county] because of the surcharges and all that." He reported being sentenced to a total of $\$ 3,000$ to $\$ 4,000$ in fines and surcharges. When he didn't pay, they were converted into liens. He continued: "Yeah. The civil judgements that they lien on you. So it's a big lien. ... Yeah, you can't buy because you owe us this. It's like asking the bank, 'Can I get this house?' [and they answer] 'Oh no, you can't do it because of [the liens].'”

Christine, a thirty-two-year-old White woman in Washington, echoed Prentice's sentiments and conveyed with frustration how having LFOs delayed her entry into homeownership.

So what should've taken me like two years to get my credit up and do whatever, it's like, "Oh I can't even do that 'cause first I gotta take care of this [court debt]. And I gotta pay this off. And until I can pay this off I can't do this." ... I'm on my fifth year. Fifth year for something that should've taken me two years at the most. Starting from zero credit to getting credit up to buy a house. It should take you no time. But if you have all these things showing up on your record. And then you're worried about, "Okay, well I can't even find anywhere to live let alone save up money to get a house." ... You're in desperate need of being able to get a house 'cause you can't rent anywhere. But it's like you can't get there because you gotta take care of all these LFOs and all this stuff before you can do anything like that. So it's really just like a big cat and mouse game. If you can even get there at the end. 
Christine was grappling with two interrelated issues. On the one hand was the inability to save money for a house. Her court debtwhich included restitution stemming from a felony and four misdemeanors - totaled $\$ 8,000$, not including the interest that continued to accrue. She reported earning $\$ 2,200$ per month, and paid $\$ 1,250$ on the apartment she shared with her sister. This left little to pay her other bills and try to reduce the court debt. "Pretty much I'm barely, if I even am, paying the interest," she grumbled. On the other hand were the credit woes, which both limited her rental options and lowered her chances of qualifying for a mortgage. Considering that Christine was in her fifth year of planning to buy a house, she was still many years away from being able to do so. So Christine remained with her sister.

\section{Living with Family and Friends}

Jacob, a twenty-six-year-old White man in Georgia, was living in an apartment with his father while his wife and three children lived with her mother. Their son's school was closest to the mother-in-law's house, but Jacob did not get along with her, so he moved in with his father. At the root of this arrangement was that he and his wife couldn't afford a place of their own. Part of Jacob's financial woes were his $\$ 6,500$ in monetary sanctions and the stipulation as part of his probation that he could only work on weekends. He told us, "I'd have to work a lot of weekends just to pay $\$ 6,500$. And I can't pay to get my own place or anything like that." Jacob's story epitomizes the "symbiotic harms" that Jacob's wife and children experienced that negatively affected the "emotional, economic, and interpersonal well-being of legally innocent people" (Boches et al. 2022, this volume)

Charles, a fifty-three-year-old Black man in Illinois, and his girlfriend lived with his sister. Like Jacob, this was not his preferred living arrangement. He was paying off the last \$85 leftover from his $\$ 50$ per month probation fees, and then he would still owe the court fines and costs of \$499. His monthly income from a disability check totaled $\$ 1,000$. "I wanted to get my own place, and I have to spend money going back and forth to court, back and forth to see the probation officer, pay the probation fee, pay the court fee. It's stopping me from really get- ting my own place." Living with family does not always lead to conflict. Charles, his girlfriend, and his sister all got along well, and living with his sister reduced some of the temptations to reoffend. Nonetheless, Charles longed for housing independence as an adult.

A final example is that of Nathan, a thirtythree-year-old White man in Washington State. Nathan was one of the few people who found his monetary sanctions fair and was relieved that they were so low. This is ironic given that he was sentenced to pay $\$ 40,000$ in restitution and nearly $\$ 10,000$ in court fines and costs for a fraud case. He said contritely, "I really screwed over a few people and me only having to pay $\$ 40,000$, I was actually kinda shocked that that's all I have to pay in restitution." Despite his relief, the amount he owed made it difficult to find and pay for housing, which meant he moved a lot and leaned heavily on family and friends. He narrated his living situation as follows:

I try to [stay with my dad] as little as possible because trying to live with him's not a good idea. But just visiting him is great. But, two to three nights a month I'll stay with my dad. But for the most part, I stay with a friend of mine down in [X city] or another friend of mine out in [X town]. [I told my friends] "Hey, let me, let me help out a little bit with any of your bills since you're letting me stay here. Or let me buy some of the food and cook you guys a meal." 'Cause my friend in [X city] I stay with, it's her, her daughter, and her boyfriend. And so yeah I try to chip in as much as I can. And I mean my friend in [X town] knows that I'm paying off this legal debt and that I've got a rough go of things, and she keeps saying, "No, Nathan, don't worry about it."

Nathan has been in this residential limbo for over ten years. He was seventeen when he was convicted, spent nearly four years in a juvenile facility, and was then released to more than a decade of housing instability, including homelessness. "I have rode around on buses all night long. I have stayed in different shelters. During the summer I even found it was warm enough, saw a park bench, laid down, slept. So, 
I mean, I've had a rough go of things paying off this debt." Nathan's criminal record made it hard to get a job, but he worked off the books for a friend's moving company earning roughly $\$ 2,000$ per month. This salary made Nathan one of the more advantaged people in our sample. Still, he could not break free of living off the kindness of others, especially in the expensive housing market where he lived. It was the first thing he mentioned in the interview.

All of these cases represent what a defense attorney in Texas reported as widespread in the court system. "Yeah. I mean, I've had lots of clients that had to move to smaller houses to afford their payments, move in with family members so that they can get through their probation, borrow money from family members to pay their probation, which I'm sure is stress on the whole family." That family stress is what restarts the loop shown in figure 1. Yet even when people live alone, their financial resources are reduced because of paying LFOs.

\section{Housing Cost Burden}

Housing cost burden is a relationship between income and housing payments defined as paying 30 percent or more of one's adjusted gross income toward housing, or 50 percent or more for "severe" housing cost burden (HUD n.d.). When household financial resources are reduced by monthly payments of court fines and fees, individuals pay an even greater proportion of their available income toward housing costs. Moreover, higher housing cost burden increases the likelihood of residential mobility and eviction (Desmond 2016). Court actors were aware of these negative impacts and shared compelling stories on the topic.

A defense attorney in Missouri talked explicitly about how monetary sanctions decreased household resources available to pay housing costs. In this case, the issue was money bonds paid before conviction to secure a person's release from jail while awaiting a plea hearing or a trial. What families thought was a monetary promise that the defendant would show up in court was really more like a down payment on postconviction LFOs. The attorney explained, "Most of the conversations that I've had with them about fees after the fact are all related to getting their bond back, because it is not made clear to them when they post bond that they will not get the entire amount back when the case is over." If a defendant was found guilty, the funds from the bond were first applied to their court fines, fees, and restitution rather than returned to the person who posted it (Page, Piehowski, and Soss 2019). Because lowincome families were often floating multiple bills and debts, this came as a heartbreaking revelation. "Especially," the lawyer continued, "because a lot of times, they will be counting on that money to maybe pay their rent when they get out, because they didn't have anything." When monies on a bond are not returned, the funds available for housing decrease, increasing the housing cost burden.

A defense attorney in Georgia talked specifically about fines and fees: "For my clients it's just another bill that they're never going to be able to pay. These are already people who are one bad day away from homelessness. And this is just another thing that shaves that base they've got even thinner." "Shaving the base" captures the reduction in household resources that LFOs represent, which then contributes to the unaffordability of housing. This attorney also recognized the slippery slope from paying too much for housing to not having housing at all.

A prosecutor in California raised the impacts of restitution, which in many states was even more aggressively collected than fines and costs.

People come to restitution court and say, "I was prepared to pay restitution and they garnished my bank account two days before I was gonna come here, and not only did they take my restitution payment, they took my house payment. They took my rent payment. Now, you know, I'm looking at not being able to pay my rent and being evicted." Courtordered debt doesn't care. They don't collaborate with you on the timing of it and say, "Is this a good time for me to exact my debt," you know? They count to a level where they think it's worth their while, and they snatch it.

Restitution is meant to repay the victim for their losses. The prosecutor's word choice is apt at illustrating restitution's retributive func- 
tions since, in some cases, the defendant had "snatched" the money, belongings, or livelihood of someone else. At the same time, many property crimes are poverty crimes. "Exacting" monetary obligations for such crimes concretely means creating housing burden by taking money that would have gone toward housing.

A final example juxtaposes a judge in Texas and a defense attorney in Illinois. Together they illustrate an underappreciated debate among criminal legal actors on if and how much monetary sanctions are meant to hurt. In the Texas judge's mind, "when you grow up and you did something wrong you had a consequence coming." For him, LFOs were part of a consequence meant to punish and deter. "Overall," he said, "a fine and court cost will have an impact that [the defendant] will not want to return. Especially when it affects their food on the table, rent, mortgage, bills, children's needs." Hence, the kind of housing cost burden that LFOs produced was reasonable to make a defendant think twice about reoffending (on LFOs as an illustration of defendants' "responsibility," see Martin, Spencer-Suarez, and Kirk 2022; Fernandes et al. 2022, both this volume). A defense attorney in Illinois had a very different reading. on precisely the same facts. She saw the court system as "taking money away from [defendants'] children's food, or necessities, or the rent, to pay these obscene burdensome fees and costs that have nothing really to do with what they're charged with." Court actors were not uniformly sympathetic or harsh in their evaluation of court debt, but they did largely recognize their impact on people's ability to pay for the basic necessities of life, including housing. ${ }^{9}$

People paying court debt were also explicit about how it reduced their resources to pay for housing. When the interviewer asked Rodrigo, a forty-year-old Latino man from New York, about how his monetary sanctions affected his life, he began, "I screwed up last time. Should've paid the whole thing." The interviewer was a bit stunned given that few people we interviewed had the wherewithal to dispense of their court fines and fees so swiftly. "Could you have paid the whole thing at once?" she asked. He answered,

No, I couldn't. The whole thing, no. Then if I do that, how I'm gonna pay my rent? Where my kids gonna live at? . . . But I have to make the decision to at least pay some of [the fine]. So they can see that I'm making the effort. And I can have my place and maybe I can get yelled at from the judge. Right now, I mean, I don't have a job. It's really affecting me because then from the rent I gotta take that $\$ 35$ [that I owe to the court]. So it is affecting me, yes. ... If I'm late on my rent, I mean, I have to let the landlord [know]. Landlord will give me time to pay the rest of it. ... I will get a late fee on top of that, probably 25, 50 dollars, which is gonna even kill me more.

Rodrigo got a $\$ 300$ fine and $\$ 50$ surcharge for smashing the window of his own car in an apparent threat to his girlfriend. He owed less than most people we interviewed, but it still required juggling multiple expenses. It is simple to compute housing cost burden on $\$ 0$ income since any amount for rent will be greater than 30 percent. Rodrigo had been working in the fast food industry, but lost his job two months before the interview. It was unclear how he was paying his $\$ 674$ per month rent. Whatever money he had coming in was reduced by the $\$ 35$ per month he was obliged to pay the court. Paying the LFO also had the indirect effect of raising his housing costs (and thus cost burden) because of late payment fees.

\section{LFOs to Homelessness}

Bobby, a twenty-three-year-old White and Latino man in California, estimated that he had "upwards of $\$ 20,000$ " in legal debt from more than five mostly drug-related misdemeanors. In a cascading spiral of events, these expenses led directly to his homelessness. Bobby lost his

9. In our coding of the court actor interviews, we found that sympathetic statements and descriptions (ninetyone) were more numerous than harsh statements or descriptions (seventy-one), but in the courtroom observations incidents of harsh treatment toward people's housing situation (ten) very slightly outnumbered the sympathetic ones (nine). 
driver's license because his "fines stacked up so high." This was especially devastating in California. To get his license back, Bobby entered a $\$ 500$ per month payment agreement. The money was deducted directly from his check from the Domino's Pizza job he had at the time. Soon the deduction overwhelmed his income. Housing was the first casualty. Bobby recounted, "I got kicked out of my apartment because of that. I couldn't afford my apartment anymore. My roommate had to find a new roommate. I lost my apartment. I was homeless for a long time, actually. While still working a job." Bobby did not lose his apartment because he was incarcerated. He was not denied housing because of a criminal background or credit check. Instead, his homelessness was directly linked to the hefty LFOs he had accumulated without any dispensation for his low income or consideration of housing costs.

Corey, a thirty-nine-year-old White man in Minnesota, similarly had money deducted from his check, which similarly led to his losing his housing. A $\$ 100$ per month garnishment "really short handed me on a lot of things," he reported, and the chain reaction started from there. "I really had to downsize a lot of things. I had lost the one-bedroom apartment I was in, and had to go down to an efficiency. That led to being homeless. I was homeless for about six months, traveling from shelter to shelter." Many respondents described this trade-off between paying their fines and fees and their other bills, including rent. Some slipped all the way to homelessness as a result.

A final example is Lester, a fifty-two-year-old White man in Washington State. Lester had been in this situation before. It was his second conviction for driving while intoxicated and he knew the steep financial penalties such crimes entailed. "The first time," he remembered, "I had somebody that I could stay and work and get enough money and they gave me cheap rent. And then I just paid it all off. But this time I didn't have anything like that. I was basically on my own. I couldn't really pay anything off, and then it just got so out of hand, and I ended up homeless." Lester knew that driving drunk was wrong. He was contrite. What lesson did he learn? "Well, first thing, don't do it.... Thank God I never hit anybody." But Lester also recognized the deep inequalities that monetary fines created in the universe of people who drive drunk. "You play, you pay," he said, "and hopefully you've got means to do that. I mean, I didn't. That's where I went totally down the hole." Some people can bounce back from a drunk driving fine, but it sent Lester into homelessness. To survive on the streets Lester "bums money," or panhandles. In 2016, the Washington Supreme Court ruled in City of Lakewood v. Willis that anti-panhandling ordinances violated people's right to free speech. ${ }^{10}$ Lester would not run afoul of the law in Washington on those grounds. He picked up various other small cases for open container and trespassing violations, however. And so the full circle closes. Lester's court debt crashed him into homelessness and the illegality of his homelessness begets more court debt.

\section{DISCUSSION AND CONCLUSION}

We have deployed multiple data sources to illustrate the housing instability-LFO nexus, or the churning of low-income people between housing hardship and criminal legal impoverishment. As figure 1 makes clear, driving this relationship is the fact of economic fragility, as well as a number of personal and structural conditions that both contribute to and exacerbate economic disadvantage. In other words, more affluent individuals avoid this nexus because they can pay for both their housing costs and their LFOs without inordinate stress.

These findings contribute to two distinct literatures. First, the focus on incarceration in the research on collateral consequences is too narrow. It is well established that incarceration leads to housing instability. But monetary sanctions are a ubiquitous part of criminal sentencing that directly reduce household resources available to pay for the most basic of provisions. Moreover, although research has documented the general economic stress that monetary sanctions pose for many people, we offer the first focused treatment of housing outcomes, going beyond homelessness to include a range of experiences of housing instability.

10. City of Lakewood v. Willis, 360 P. 3d 817 (2015). 
Second, we contribute to the research on housing by uncovering monetary sanctions as an understudied contributor to housing problems. If the basic cause of housing insecurity is limited resources, then having to pay monetary sanctions further limits resources available to pay housing costs. To be clear, monetary sanctions are not a primary contributor to housing stress. As the Federal Reserve data show, only 6 percent of respondents had outstanding legal obligations. However, the figure rises to 10 percent among families earning less than \$40,000 (Federal Reserve 2020a, box 2, table A). Given that the question asks only about current debt, the prevalence of having ever experienced court debt is likely much greater, and thus the impact on housing is also likely more widespread.

Additional research could help strengthen our findings. With our data, we cannot identify the independent effects of LFOs-as separate from more generalized financial strain-on people's housing situations. In other words, how much (if at all) do monetary sanctions push already financially strapped people into housing insecurity? Also, the recursive nature of our model makes it difficult to discern whether housing insecurity precedes receiving a fine and fee sentence, or if the opposite is true. To answer both of these questions requires longitudinal data that include both criminal legal and housing histories. Both the National Longitudinal Survey of Youth and the Fragile Families Study have been used to study the relationship between criminal legal involvement and housing outcomes. The survey questionnaires, however, do not include questions on monetary sanctions or court debt. As far as we can tell, neither do studies that have followed people's housing trajectories once they are released from prison. Many of those men and women have criminal legal debt because fines and fees are usually in addition to, not instead of, incarceration. Additional survey data on LFO's would allow for a comparison of housing trajectories for returnees across LFO amounts or by payment status. This would address the question of the direct effect of LFOs on housing outcomes but leave open the question of how housing instability leads to LFOs. We have shown qualitatively how unstable housing situations like living with family members and frequent residential moves make people vulnerable to criminal legal contact, including LFOs. Prospective longitudinal surveys of low- and middle-income families that include information about housing, criminal convictions, and financial sentences would make it possible to quantitatively study the housing instability-LFO pathway uncovered in our research.

Regarding policy, our findings point first to the priority of decriminalizing homelessness (National Homelessness Law Center 2019). Our research shows not only the destabilizing effects of incarceration but also the direct financial impact of LFOs, which makes it impossible for people already experiencing homelessness to recover from court debt and afford housing, and pushes economically fragile individuals into homelessness. Our research also argues for substantial expansion of housing subsidies. Only 18 percent of the people we interviewed received any form of government housing assistance, even though most met the income criteria. As a result, many interviewees were unable to set up their own households and were compelled to live with family and friends, straining the limits of others' generosity. Eligibility rules for housing subsidies also need reform, especially in shortening the "lookback" period for criminal records and providing waivers for several categories of misdemeanor offenses (Walter, Viglione, and Tillyer 2017). Finally, reading our findings alongside those of Bryan Sykes and his colleagues (2022, this volume) cautions against siphoning off housing assistance funds into the criminal legal system through LFOs. People who receive housing assistance should be automatically deemed unable to pay LFOs, eliminating LFOs as part of the sentence.

Overall, our research spotlights the housingrelated implications of criminalizing poverty. Even many of the court actors who we interviewed overlooked this point. A defense attorney in Illinois told us, "I mean I hear people complain, but I'm going to be honest, after twenty years, and also knowing I can't do anything about that [fine or fee] amount, and the fact that you can't find a job and you got put out of your house, I'm only listening with one 
ear. Sad as that is." Empirically identifying the housing instability-LFO nexus, as we have done in this article, may serve to open the other ear.

\section{REFERENCES}

Bannon, Alicia, Mitali Nagrecha, and Rebekah Diller. 2010. Criminal Justice Debt: A Barrier to Re-entry. New York: Brennan Center for Justice. https:// www.brennancenter.org/sites/default/files /2019-08/Report_Criminal-Justice-Debt-\%20A -Barrier-Reentry.pdf.

Beckett, Katherine, and Steve Herbert. 2008. "Dealing with Disorder: Social Control in the Postindustrial City." Theoretical Criminology 12(1): 5-30.

Boches, Daniel J., Brittany T. Martin, Andrea Giuffre, Amairini Sanchez, Aubrianne L. Sutherland, and Sarah K.S. Shannon. 2022. "Monetary Sanctions and Symbiotic Harms." RSF: The Russell Sage Foundation Journal of the Social Sciences 8(2): 98-115. DOI: https://doi.org/10.7758/RSF.2022 .8.2.05

Bryan, Brielle. 2020. “Homeownership Experiences Following Criminal Justice Contact." Cityscape 22(1): 103-46.

Clark, Valerie A. 2016. "Predicting Two Types of Recidivism Among Newly Released Prisoners: First Addresses as 'Launch Pads' for Recidivism or Reentry Success." Crime \& Delinquency 62(10): 1364-400.

Cobb-Clark, Deborah A., and Anna Zhu. 2017. "Childhood Homelessness and Adult Employment: The Role of Education, Incarceration, and Welfare Receipt." Journal of Population Economics 30(3): 893-924.

Cobbina, Jennifer E. 2010. “Reintegration Success and Failure: Factors Impacting Reintegration Among Incarcerated and Formerly Incarcerated Women." Journal of Offender Rehabilitation 49(3): 210-32.

Couloute, Lucius. 2018. Nowhere to Go: Homelessness Among Formerly Incarcerated People. Northampton, Mass.: Prison Policy Initiative. Accessed August 14, 2021. https://www.prison policy.org/reports/housing.html.

Cox, Robynn, Benjamin Henwood, Seva Rodnyansky, Eric Rice, and Suzanne Wenzel. 2019. "Road Map to a Unified Measure of Housing Insecurity." Cityscape 21(2): 93-128.

Cox, Robynn, John Lahey, Harmony Rhoades, Benja- min Henwood, and Suzanne Wenzel. 2021. “Does the Timing of Incarceration Impact the Timing and Duration of Homelessness? Evidence from 'The Transitions to Housing' Study." Justice Quarterly 38(6): 1070-94.

Desmond, Matthew. 2016. Evicted: Poverty and Profit in the American City. New York: Crown Publishing Group.

Evans, Linda. 2007. “Locked Up, Then Locked Out: Women Coming Out of Prison." Women \& Therapy 29(3-4): 285-308.

Evans, Douglas N., and Jeremy R. Porter. 2015. "Criminal History and Landlord Rental Decisions: A New York Quasi-Experimental Study." Journal of Experimental Criminology 11(1): 21-42.

Federal Reserve. 2020a. "Report on the Economic Well-Being of U.S. Households in 2019, Featuring Supplemental Data from April 2020." Washington, DC: Federal Reserve Board. Accessed August 12, 2021. https://www.federalreserve.gov /publications/files/2019-report-economic-well -being-us-households-202005.pdf.

—. 2020b. "Survey of Household Economics and Decisionmaking." Washington, DC: Federal Reserve Board. Accessed August 12, 2021. https:// www.federalreserve.gov/consumerscommunities /shed.htm.

Fernandes, April D. Brittany Friedman, and Gabriela Kirk. 2022. "The 'Damaged' State vs. the 'Willful' Nonpayer: Pay to Stay and the Social Construction of Damage, Harm, and Moral Responsibility in a Rent-Seeking Society." RSF: The Russell Sage Foundation Journal of the Social Sciences 8(1): 82-105. DOI: https://doi.org/10.7758/RSF .2022.8.1.04.

Geller, Amanda, and Marah A. Curtis. 2011. "A Sort of Homecoming: Incarceration and The Housing Security of Urban Men." Social Science Research 40(4): 1196-213.

Geller, Amanda, and Allyson Walker Franklin. 2014. "Paternal Incarceration and the Housing Security of Urban Mothers." Journal of Marriage and Family 76(2): 411-27.

Gowan, Teresa. 2002. "The Nexus: Homelessness and Incarceration in Two American Cities." Ethnography 3(4): 500-34.

Greenberg, Greg A., and Robert A. Rosenheck. 2008. "Jail Incarceration, Homelessness, and Mental Health: A National Study." Psychiatric Services 59(2): 170-77.

Halushka, John M. 2020. “The Runaround: Punish- 
ment, Welfare, and Poverty Survival After Prison." Social Problems 67(2): 233-50.

Harding, David J., Jeffrey D. Morenoff, and Claire W. Herbert. 2013. "Home Is Hard to Find: Neighborhoods, Institutions, and the Residential Trajectories of Returning Prisoners." The Annals of the American Academy of Political and Social Science 647(1): 214-36.

Harlow, Caroline Wolf. 2003. “Education and Correctional Populations." BJS Special Report NCJ 195670. Washington: U.S. Department of Justice. Accessed August 12, 2021. https://www.bjs.gov /content/pub/pdf/ecp.pdf.

Harris, Alexes. 2016. A Pound of Flesh: Monetary Sanctions as Punishment for the Poor. New York: Russell Sage Foundation.

Harris, Alexes, Heather Evans, and Katherine Beckett. 2010. “Drawing Blood from Stones: Legal Debt and Social Inequality in the Contemporary United States." American Journal of Sociology 115(6): 1753-99.

Harris, Alexes, Mary Pattillo, and Bryan L. Sykes. 2022. "Studying the System of Monetary Sanctions." RSF: The Russell Sage Foundation Journal of the Social Sciences 8(1): 1-33. DOI: https://doi .org/10.7758/RSF.2022.8.1.01.

Herbert, Claire W., Jeffrey D. Morenoff, and David J.

Harding. 2015. "Homelessness and Housing Insecurity Among Former Prisoners." RSF: The Russell Sage Foundation Journal of the Social Sciences 1(2): 44-79. DOI: https://doi.org/10.7758 /RSF.2015.1.2.04.

Herring, Chris, Dilara Yarbrough, and Lisa Marie Alatorre. 2020. "Pervasive Penality: How the Criminalization of Poverty Perpetuates Homelessness." Social Problems 67(1): 131-49.

Jacobs, Leah A., and Aaron Gottlieb. 2020. “The Effect of Housing Circumstances on Recidivism: Evidence from a Sample of People on Probation in San Francisco." Criminal Justice \& Behavior 47(9): 1097-115.

James, Doris. 2004. "Profile of Jail Inmates, 2002."

Bureau of Justice Statistics Special Report NCJ 201932. Washington: U.S. Department of Justice. Accessed August 12, 2021. https://www.bjs.gov /content/pub/pdf/pji02.pdf.

Keene, Danya E., Amy B. Smoyer, and Kim M. Blankenship. 2018. "Stigma, Housing and Identity After Prison." The Sociological Review 66(4): 799815.
Kirk, David S., Geoffrey C. Barnes, Jordan M. Hyatt, and Brook W. Kearley. 2018. "The Impact of Residential Change and Housing Stability on Recidivism: Pilot Results from the Maryland Opportunities Through Vouchers Experiment (MOVE)." Journal of Experimental Criminology 14(2): 21326.

Martin, Karin D., Kimberly Spencer-Suarez, and Gabriela Kirk. 2022. “Pay or Display: Monetary Sanctions and Performance of Accountability and Procedural Integrity in New York and Illinois Courts." RSF: The Russell Sage Foundation Journal of the Social Sciences 8(1): 128-47. DOI: https://doi.org/10.7758/RSF.2022.8.1.06.

Martin, Karin D., Bryan L. Sykes, Sarah K.S. Shannon, Frank Edwards, and Alexes Harris. 2018. “Monetary Sanctions: Legal Financial Obligations in US Systems of Justice." Annual Review of Criminology 1(1): 471-95.

Metraux, Stephen, Caterina G. Roman, and Richard S. Cho. 2007. "Incarceration and Homelessness." Paper presented at the National Symposium on Homelessness Research, U.S. Department of Housing and Urban Development. Washington (March 1-2, 2007). Accessed August 12, 2021. https://aspe.hhs.gov/system/files/pdf/174201 /report.pdf\#page=337.

Mogk, Jessica, Valerie Shmigol, Marvin Futrell, Bert Stover, and Amy Hagopian. 2020. “CourtImposed Fines as a Feature of the Homelessness Incarceration Nexus: A Cross-Sectional Study of the Relationship Between Legal Debt and Duration of Homelessness in Seattle, Washington, USA." Journal of Public Health 42(2): e107-19.

Muentner, Luke, Nicole Holder, Cynthia Burnson, Hilary Runion, Lindsay Weymouth, and Julie Poehlmann-Tynan. 2019. “Jailed Parents and their Young Children: Residential Instability, Homelessness, and Behavior Problems." Journal of Child and Family Studies 28(2): 37086.

National Homelessness Law Center. 2019. Housing Not Handcuffs 2019. Washington, DC: National Homelessness Law Center. Accessed August 12, 2021. http://nlchp.org/wp-content/uploads/2019 /12/HOUSING-NOT-HANDCUFFS-2019-FINAL. pdf.

Page, Joshua, Victoria Piehowski, and Joe Soss. 2019. "A Debt of Care: Commercial Bail and the 
Gendered Logic of Criminal Justice Predation." RSF: The Russell Sage Foundation Journal of the Social Sciences 5(1): 150-72. DOI: https://doi.org /10.7758/RSF.2019.5.1.07.

Pattillo, Mary. 2013. “Housing: Commodity Versus Right." Annual Review of Sociology 39(1): 50931.

Petersilia, Joan. 2003. When Prisoners Come Home: Parole and Prisoner Reentry. New York: Oxford University Press.

Richie, Beth E. 2001. “Challenges Incarcerated Women Face as They Return to Their Communities: Findings from Life History Interviews." Crime \& Delinquency 47(3): 368-89.

Schneider, Daniel, and Kristin Turney. 2015. “Incarceration and Black-White Inequality in Homeownership: A State-Level Analysis." Social Science Research 53 (September): 403-14.

Shinn, Marybeth, and Jill Khadduri. 2020. In the Midst of Plenty: Homelessness and What to Do About It. New York: John Wiley \& Sons.

Steiner, Benjamin, Matthew D. Makarios, and Lawrence F. Travis III. 2015. “Examining the Effects of Residential Situations and Residential Mobility on Offender Recidivism." Crime \& Delinquency 61(3): 375-401.

Stuart, Forrest. 2016. Down, Out, and Under Arrest: Policing and Everyday Life in Skid Row. Chicago: University of Chicago Press.

Sykes, Brian L., Meghan Ballard, Andrea Giuffre, Rebecca Goodsell, Daniela Kaiser, Vicente Celestino Mata, and Justin Sola. 2022. “Robbing Peter to
Pay Paul: Public Assistance, Monetary Sanctions, and Financial Double-Dealing in America." RSF: The Russell Sage Foundation Journal of the Social Sciences 8(1): 148-78. DOI: https://doi.org /10.7758/RSF.2022.8.1.07.

Thacher, David. 2008. "The Rise of Criminal Background Screening in Rental Housing." Law \& Social Inquiry 33(1): 5-30.

U.S. Department of Housing and Urban Development (HUD). n.d. "Rental Burdens: Rethinking Affordability Measures." Edge: An Online Magazine. HUDUser. https://www.huduser.gov/portal /pdredge/pdr_edge_featd_article_092214.html.

Walter, Rebecca J., Jill Viglione, and Marie Skubak Tillyer. 2017. “One Strike to Second Chances: Using Criminal Backgrounds in Admission Decisions for Assisted Housing." Housing Policy Debate 27(5): 734-50.

Warner, Cody. 2015. “On the Move: Incarceration, Race, and Residential Mobility." Social Science Research 52(July): 451-64.

Western, Bruce. 2018. Homeward: Life in the Year After Prison. New York: Russell Sage Foundation.

Wildeman, Christopher. 2014. “Parental Incarceration, Child Homelessness, and the Invisible Consequences of Mass Imprisonment." The Annals of the American Academy of Political and Social Science 651(1): 74-96.

Zgoba, Kristen M., Jill Levenson, and Tracy McKee. 2009. "Examining the Impact of Sex Offender Residence Restrictions on Housing Availability." Criminal Justice Policy Review 20(1): 91-110. 